\title{
PRORAČUN PRODORA KLORIDA U BETON
}

\author{
ANALYSIS OF CHLORIDE PENETRATION IN \\ CONCRETE
}

\author{
Anton Bogdanić* , Joško Ožbolt ${ }^{* *}$
}

\begin{abstract}
Sažetak
$\mathrm{Na}$ armiranobetonskim konstrukcijama izloženim agresivnom okolišu često nastaju oštećenja uslijed korozije armature izazvane kloridnim ionima. Oštećenja nastaju u obliku pukotina i odlamanja zaštitnog sloja betona uslijed bubrenja produkata korozije, što nepovoljno utječe na nosivost i trajnost konstrukcije. Povrh toga, površina poprečnog presjeka armature smanjuje se istovremeno s procesom degradacije betona. No, oštećenja se javljaju neposredno nakon depasivacije čelika uslijed kritične koncentracije kloridnih iona u blizini armature. Vrijeme koje je potrebno da kritična koncentracija kloridnih iona prodre do armature naziva se faza inicijacije, a osnovni cilj ovog rada je procjena njezinog trajanja. Trajanje faze inicijacije moguće je predvidjeti ukoliko se u obzir uzmu transportni procesi koji se odvijaju kroz zaštitni sloj betona. Najvažniji fizikalni procesi vezani uz fazu inicijacije su transport kapilarne vode, kloridnih iona te topline. Stoga je u okviru ovog rada razvijen $2 D$ numerički model pomoću metode konačnih razlika, koji simulira navedene transportne procese. Primjena modela pokazana je na numeričkom primjeru u kojem je kvadratni poprečni presjek armiranobetonskog stupa izložen agresivnim morskim uvjetima. Proračun je proveden kako bi se istražio utjecaj širine pukotina na trajanje faze inicijacije. Numerički rezultati pokazuju da raspucalost zaštitnog sloja betona značajno smanjuje trajanje faze inicijacije, a samim time $i$ uporabni vijek konstrukcija.
\end{abstract}

Ključne riječi: korozija, armirani beton, transportni procesi, faza inicijacije, metoda konačnih razlika

\footnotetext{
* Sveučilište u Rijeci, Građevinski fakultet, Radmile Matejčić 3, 51000 Rijeka E-mail: anton.bogdanic@gradri.uniri.hr

** Sveučilište u Stuttgartu, Institut za građevinske materijale, Pfaffenwaldring 4, 70569 Stuttgart E-mail: ozbolt@iwb.uni-stuttgart.de
} 


\begin{abstract}
Reinforced concrete structures exposed to aggressive environmental conditions often exhibit damage caused by chloride-induced corrosion of reinforcement. The damage occurs in the form of cracking and spalling of the concrete cover due to the expansion of corrosion products, which adversely affects the bearing capacity and durability of structures. Moreover, the cross-sectional area of reinforcement decreases simultaneously with concrete deterioration. However, the damage occurs shortly after steel depassivation caused by critical chloride concentration in the vicinity of the reinforcement. The time necessary for critical chloride concentration to reach the reinforcement is called initiation phase and the main objective of this paper is to estimate its duration. The duration of the initiation phase is possible to predict if transport processes, which take place through the concrete cover, are accounted for. The most important physical processes related to steel depassivation are the transport of capillary water, chloride and heat. Therefore, the development of a $2 D$ is presented in this paper. The model is based on the finite difference method and simulates aforementioned transport processes. The application of the model is shown on a numerical example in which a square cross-section of a reinforced concrete column is exposed to aggressive maritime conditions. The analysis is carried out to investigate the influence of crack width in concrete cover on the duration of the initiation phase. The numerical results show that the cracking of concrete cover significantly reduces the duration of the initiation phase, and, consequently, the service life of structures.
\end{abstract}

Key words: corrosion, reinforced concrete, transport processes, initiation phase, finite difference method

\title{
1. Uvod
}

Korozija armature izazvana prisutnošću kloridnih iona jedan je od glavnih uzroka za skraćenje uporabnog vijeka armiranobetonskih konstrukcija izloženih agresivnom okolišu. Dakle, najugroženije su konstrukcije u blizini mora ili one izložene solima za odmrzavanje. Armaturi zahvaćenoj korozijom postepeno se smanjuje površina poprečnog presjeka, a istovremeno nastaju produkti korozije čiji je volumen i do šest puta veći od volumena pasivne armature [1]. Povećanje volumena uzrokuje dodatna naprezanja $\mathrm{u}$ betonu u blizini armature koja mogu rezultirati pukotinama i odlamanjem zaštitnog sloja betona. Oštećenja u zaštitnom sloju, uzrokovana bubrenjem korozijskih produkata ili nekim drugim djelovanjima, pogoduju prodoru agresivnih tvari te ubrzavaju proces korozije [2]. Spomenuta oštećenja betona i armature negativno utječu na nosivost i trajnost cijele konstrukcije.

Proces korozije moguće je promatrati kroz dva vremenska perioda koji se nazivaju faza inicijacije i faza propagacije [3],[4]. Tijekom faze 
inicijacije kloridni ioni prodiru u zaštitni sloj betona. U određenom trenutku uporabnog vijeka konstrukcije javlja se depasivacija armature, tj. oštećenje pasivnog sloja armature uslijed kritične koncentracije kloridnih iona. Depasivacija armature predstavlja početak faze propagacije tijekom koje dolazi do elektrokemijskog razaranja čelika i stvaranja korozijskih produkata. Dakle, važno je da faza inicijacije potraje što dulje kako bi oštećenje konstrukcije uslijed procesa korozije nastalo čim kasnije.

Stoga je cilj ovog rada uz pomoć dvodimenzionalnog numeričkog modela predvidjeti trajanje faze inicijacije. Kako bi rezultati modela bili što vjernija slika stvarnog stanja, potrebno je riješiti linearne i nelinearne parcijalne diferencijalne jednadžbe koje opisuju transportne procese tijekom faze inicijacije.

U okviru rada objašnjeni su transportni procesi te je ukratko prikazan postupak njihovog modeliranja pomoću metode konačnih razlika. Osim toga, prikazani su i rezultati parametarske analize gdje je model upotrijebljen kako bi se ispitao utjecaj širine pukotine u zaštitnom sloju betona na trajanje faze inicijacije.

\section{Transportni procesi tijekom faze inicijacije}

Tijekom faze inicijacije odvijaju se transporti kapilarne vode, topline, kisika, kloridnih te $\mathrm{OH}^{-}$iona. Za trajanje faze inicijacije svakako je najvažniji transport kloridnih iona. No, dokazano je da raspodjela kapilarne vode i temperature direktno utječu na transport kloridnih iona [5]. Dakle, kako bi se čim preciznije odredilo trajanje faze inicijacije, potrebno je u obzir uzeti transporte kapilarne vode, topline i kloridnih iona. Sukladno navedenom, transport kisika te $\mathrm{OH}^{-}$iona nisu uzeti u obzir unutar ovog rada.

Pretpostavljajući da je proces hidratacije u betonu završen, model za opisivanje transportnih procesa u dvodimenzionalnom prostoru i vremenu uključuje varijable:

- $\theta_{\mathrm{w}}(\mathrm{x}, \mathrm{y}, \mathrm{t})$ - volumni udio porne vode u betonu $\left(\mathrm{m}^{3}{ }_{\text {vode }} / \mathrm{m}^{3}{ }_{\text {betona }}\right)$,

- $C_{\mathrm{c}}(\mathrm{x}, \mathrm{y}, \mathrm{t})$ - koncentracija slobodnih kloridnih iona $\left(\mathrm{kg}_{\mathrm{cl}}-/ \mathrm{m}^{3}\right.$ porne otopine)

- $C_{\mathrm{cb}}(\mathrm{x}, \mathrm{y}, \mathrm{t})$ - koncentracija vezanih kloridnih iona $\left(\mathrm{kg}_{\mathrm{cl}} / \mathrm{m}^{3}\right.$ betona $)$

- $T(\mathrm{x}, \mathrm{y}, \mathrm{t})$ - temperatura u poprečnom presjeku $\left({ }^{\circ} \mathrm{C}\right)$

\subsection{Transport kapilarne vode}

Transport kapilarne vode opisan je preko nelinearne paraboličke parcijalne diferencijalne jednadžbe [6]:

$$
\frac{\partial \theta_{\mathrm{w}}}{\partial t}=\nabla\left(D_{\mathrm{w}}\left(\theta_{\mathrm{w}}\right) \nabla \theta_{\mathrm{w}}\right)
$$


pri čemu nelinearnost proizlazi iz činjenice da je koeficijent difuzije kapilarne vode $D w\left(\mathrm{~m}^{2} / \mathrm{s}\right)$ ovisan o volumnom udjelu porne vode $\theta w$. Ovisnost koeficijenta difuzije o sadržaju vlage može se opisati pomoću eksponencijalne funkcije koja glasi:

$$
D_{\mathrm{w}}=D_{0} e^{n \bar{\theta}_{w}},
$$

gdje je konstanta granična vrijednost, a $n$ je faktor oblika. Član $\bar{\theta}_{w}=$ $\left(\theta_{\mathrm{w}}-\theta_{\mathrm{wi}}\right) /\left(\theta_{\mathrm{wd}}-\theta_{\mathrm{wi}}\right)$ je normirani sadržaj vode, pri čemu su $\theta_{\mathrm{wd}}$ i $\theta_{\mathrm{wi}}$ saturirani i početni sadržaj vode.

\subsection{Transport kloridnih iona}

Kloridni ioni tijekom faze inicijacije prodiru $u$ beton različitim transportnim mehanizmima poput difuzije, konvekcije, apsorpcije itd. [2]. Većina matematičkih modela koji opisuju transport kloridnih iona uključuje samo difuziju. Najjednostavniji jednodimenzionalni matematički model, koji se temelji na pretpostavci da je koeficijent difuzije $D_{0}$ konstantan, glasi:

$$
\frac{\partial C}{\partial t}=D_{0} \frac{\partial^{2} C}{\partial x^{2}}
$$

Jednadžba (1) je linearna parabolička diferencijalna jednadžba za koju, uz određene pretpostavke, postoji i analitičko rješenje. No, modeli bazirani na difuziji primjenjivi su za konstrukcije konstantne vlažnosti, ali podcjenjuju količinu kloridnih iona u konstrukcijama koje su izložene procesima sušenja i vlaženja. U zonama sušenja i vlaženja potrebno je uzeti u obzir i transport kloridnih iona uslijed gibanja kapilarne vode u kojoj su otopljeni [1]. Navedena pojava naziva se konvekcija i odvija se puno brže od difuzije.

Osim difuzije i konvekcije, u obzir je uzeto i vezivanje kloridnih iona za produkte hidratacije. Stoga se transport kloridnih iona može opisati pomoću sljedeće nelinearne parcijalne diferencijalne jednadžbe [6]:

$$
\theta_{\mathrm{w}} \frac{\partial C_{c}}{\partial t}=\nabla\left(\theta_{\mathrm{w}} D_{c}(h, T) \nabla C_{\mathrm{c}}\right)+D_{\mathrm{w}}\left(\theta_{\mathrm{w}}\right) \nabla \theta_{\mathrm{w}} \nabla C_{\mathrm{c}}-\frac{\partial C_{c b}}{\partial t},
$$

gdje je $D_{C}\left(\mathrm{~m}^{2} / \mathrm{s}\right)$ koeficijent difuzije kloridnih iona. Koeficijent difuzije izražen je kao funkcija relativne vlažnosti u porama $h$ i temperature betona $T$ :

$$
D_{c}(h, T)=D_{c, R e f} \cdot\left[1+\frac{(1-h)^{4}}{\left(1-h_{c}\right)^{4}}\right]^{-1} \cdot \exp \left[\frac{U}{R}\left(\frac{1}{T_{R e f}}-\frac{1}{T}\right)\right],
$$

pri čemu je $D_{c, \text { Ref }}$ referentna vrijednost za standardne uvjete $\left(T_{R e f}=23^{\circ} \mathrm{C}\right.$, $t_{e}=28$ dana, $h=1$ ), konstanta ima vrijednost 0.75 [1], a $U$ i $R$ su aktivacijska energija za proces difuzije klorida te univerzalna plinska konstanta. 
Za određivanje odnosa relativne vlažnosti $h$ te udjela kapilarne vode $\theta_{w}$ korišten je tzv. BSB adsorbcijske izoterme. Detalje vezane uz BSB model moguće je pronaći u [1]. Jednadžba koja daje linearnu zavisnost koncentracije vezanih i slobodnih kloridnih iona je sljedeća:

$$
\frac{\partial C_{\mathrm{cb}}}{\partial t}=k_{r}\left(\alpha C_{c}-C_{c b}\right),
$$

pri čemu je $k_{r}$ koeficijent vezivanja (1/s), dok konstanta $\alpha$ opisuje vezu slobodnih i vezanih kloridnih iona, a u ovom radu usvojena je vrijednost $\alpha=0.7$ [2],[7].

U literaturi se mogu pronaći modeli temeljeni isključivo na difuziji, pri čemu se koeficijent difuzije uzima kao konstantna varijabla [8]. Iako su takvi modeli znatno jednostavniji za implementaciju, njihova primjena na stvarne konstrukcije je ograničena jer su konstrukcije u pravilu izložene sušenju i vlaženju te konstantnoj promjeni temperature betona i vlažnosti pora. Stoga je za općenitu primjenu vrlo važno u jednadžbe uključiti konvektivni dio, vezivanje slobodnih klorida, kao i ovisnost koeficijenta difuzije o temperaturi i vlažnosti pora.

\subsection{Prijenos topline}

Distribucija temperature u poprečnom presjeku dobivena je na temelju konstitutivnog zakona za protok topline i očuvanja energije putem sljedeće linearne parcijalne diferencijalne jednadžbe [7]:

$$
\lambda \Delta T-c \rho \frac{\partial T}{\partial t}=0 .
$$

Za razliku od (1) i (4), jednadžba (7) je linearna jer su toplinska vodljivost $\lambda(\mathrm{W} /(\mathrm{m} \cdot \mathrm{K}))$, toplinski kapacitet $c(\mathrm{~J} /(\mathrm{kg} \cdot \mathrm{K}))$ te gustoća $\rho\left(\mathrm{kg} / \mathrm{m}^{3}\right)$ uzeti kao konstantni parametri.

\section{Numerički model}

Složene parcijalne diferencijalne jednadžbe koje opisuju fizikalne procese u prirodi najčešće je nemoguće riješiti analitičkim putem. Stoga je razvijen niz numeričkih metoda pomoću kojih je moguće dobiti približno rješenje promatranog problema. U ovom radu vremenska i prostorna diskretizacija parcijalnih diferencijalnih jednadžbi provedena je pomoću metode konačnih razlika koja diferencijalnu jednadžbu pretvara u sustav linearnih ili nelinearnih jednadžbi. Treba naglasiti da su se sustavi nelinearnih jednadžbi rješavali pomoću Newtonove metode koja se vrlo često primjenjuje u tu svrhu. 


\subsection{Vremenska i prostorna diskretizacija}

Jednadžba (7), najjednostavnija od korištenih jednadžbi, poslužit će kao primjer za vremensku i prostornu diskretizaciju u pravokutnom ravninskom koordinatnom sustavu. Laplaceov operator u ravninskom pravokutnom koordinatnom sustavu poprima oblik:

$$
\Delta=\nabla^{2}=\frac{\partial^{2}}{\partial \mathrm{x}^{2}}+\frac{\partial^{2}}{\partial \mathrm{y}^{2}}
$$

Jednadžbu (7) možemo zapisati na sljedeći način:

$$
\frac{\partial T}{\partial t}=\frac{\lambda}{c \rho}\left(\frac{\partial^{2} T}{\partial \mathrm{x}^{2}}+\frac{\partial^{2} T}{\partial \mathrm{y}^{2}}\right)
$$

Pri diskretiziranju jednadžbi koristila se implicitna shema (tzv. Backward Euler) u kojoj prostorne derivacije diskretiziramo u vremenskom koraku $n+1$. Zamijenimo li derivacije u (9) s konačnim razlikama, pri tome koristeći implicitnu shemu, dobivamo diskretiziranu jednadžbu:

$$
\frac{T_{i, j}^{n+1}-T_{i, j}^{n}}{\Delta t}=\frac{\lambda}{c \rho}\left(\frac{T_{i-1, j}^{n+1}-2 T_{i, j}^{n+1}+T_{i+1, j}^{n+1}}{\Delta \mathrm{x}^{2}}+\frac{T_{i, j-1}^{n+1}-2 T_{i, j}^{n+1}+T_{i, j+1}^{n+1}}{\Delta \mathrm{y}^{2}}\right),
$$

pri čemu je $\Delta t$ vremenski korak, a $\Delta x$ i $\Delta y$ su prostorni koraci. Jednadžba (10) vrijedi za svaki čvor diskretiziranog modela, pri čemu treba paziti da se rubni uvjeti uzmu u obzir u jednadžbama rubnih čvorova.

Na sličan način diskretizirane su sve parcijalne diferencijalne jednadžbe, a kao primjer još se može izdvojiti prostorna diskretizacija difuzivnog člana u (1). U nastavku se prikazuje izvod za jednu prostornu varijablu jer je za drugu prostornu varijablu postupak identičan. Osim toga, u članovima je izostavljena oznaka vremenskog koraka, a pored koeficijenta difuzije ne piše se zavisnost o udjelu porne vode kako bi zapis bio čim jednostavniji.

$$
\begin{aligned}
\nabla\left(D_{\mathrm{w}}\left(\theta_{\mathrm{w}}\right) \nabla \theta_{\mathrm{w}}\right)= & \nabla\left(D_{\mathrm{w}} \nabla \theta_{\mathrm{w}}\right)=\frac{\left(D_{\mathrm{w}} \nabla \theta_{\mathrm{w}}\right)_{i+1 / 2}-\left(D_{\mathrm{w}} \nabla \theta_{\mathrm{w}}\right)_{i-1 / 2}}{\Delta x} \\
& =\frac{1}{\Delta x} \cdot\left[D_{\mathrm{w} i+1 / 2} \frac{\theta_{\mathrm{w} i+1}-\theta_{\mathrm{w} i}}{\Delta x}-D_{\mathrm{w} i-1 / 2} \frac{\theta_{\mathrm{w} i}-\theta_{\mathrm{w} i-1}}{\Delta x}\right]
\end{aligned}
$$

Treba primijetiti da su u trenutnom zapisu (11) koeficijenti difuzije izračunati u fiktivnim točkama u kojima nisu poznate vrijednost udjela porne vode. Stoga se ti članovi zapisuju preko stvarnih čvorova diskretiziranog modela na sljedeći način [8]: 


$$
\begin{aligned}
& D_{\mathrm{w} i+1 / 2} \approx \frac{1}{2} \cdot\left(D_{\mathrm{w}}\left(\theta_{\mathrm{w} i+1}\right)+D_{\mathrm{w}}\left(\theta_{\mathrm{w} i}\right)\right), \\
& D_{\mathrm{w} i-1 / 2} \approx \frac{1}{2} \cdot\left(D_{\mathrm{w}}\left(\theta_{\mathrm{w} i}\right)+D_{\mathrm{w}}\left(\theta_{\mathrm{w} i-1}\right)\right),
\end{aligned}
$$

Kombiniranjem (11), (12) i (13) dobije se diskretizirani oblik difuzivnog člana jednadžbe za transport kapilarne vode.

\subsection{Rubni uvjeti i postupak proračuna}

Prilikom određivanja distribucije topline u poprečnom presjeku korišten je Robinov rubni uvjet, pri čemu je poznata temperatura okoline $T_{E x t}$ i konvektivni koeficijent $B_{T}\left(\mathrm{~W} /\left(\mathrm{m}^{2} \cdot \mathrm{K}\right)\right)$ [9]:

$$
\lambda\left(\frac{\partial^{2} T}{\partial \mathrm{x}^{2}}+\frac{\partial^{2} T}{\partial \mathrm{y}^{2}}\right)=B_{T}\left(T-T_{E x t}\right) .
$$

Za određivanje volumnog udjela kapilarne vode i slobodnih kloridnih iona korišteni su Dirichletovi rubni uvjeti koji se u metodi konačnih razlika vrlo jednostavno uzimaju u obzir.

Kako bi se proračun mogao provesti, na početku je, osim rubnih uvjeta, potrebno zadati i početne uvjete za raspodjelu kloridnih iona, topline i kapilarne vode u početnom trenutku $t=0$. Zatim se u svakom vremenskom koraku najprije računa distribucija temperature i volumni udio kapilarne vode u poprečnom presjeku, a nakon toga dobiveni rezultati služe kao ulazni parametri za rješavanje jednadžbi vezanih uz prodor kloridnih iona.

\section{Primjena numeričkog modela}

Razvijeni numerički model iskorišten je kako bi se istražio utjecaj pukotine na koncentraciju slobodnih kloridnih iona i, posljedično, na trajanje faze inicijacije. Stoga je numerička analiza provedena za neraspucali poprečni presjek te za poprečni presjek s pukotinom širine $0,075 \mathrm{~mm}$ i $0,1 \mathrm{~mm}$. Pozicija pukotine u poprečnom presjeku prikazana je na Slici 1, a modelirana duljina pukotine je $8 \mathrm{~cm}$. Treba naglasiti da armatura nije modelirana u punom profilu, tj. ne predstavlja barijeru kloridnim ionima. 


\subsection{Parametri usvojeni u numeričkoj analizi}

Numerička analiza provedena je na primjeru kvadratnog poprečnog presjeka armiranobetonskog stupa (Slika 1). Materijalni parametri korišteni u ovoj analizi prikazani su u Tablici 1, a usvojeni su na temelju vrijednosti koje su korištene u dostupnim radovima na ovu temu [1], [2], [7].

Tablica 1. Materijalni parametri

\begin{tabular}{|l|c|c|}
\hline \multicolumn{1}{|c|}{ Parametar } & Mjerna jedinica & Vrijednost \\
\hline Vodocemetni omjer, $v / c$ & - & 0,36 \\
\hline Ekvivalentno vrijeme hidratacije, $t_{e}$ & dani & 180 \\
\hline Koeficijent vezivanja, $k_{r}$ & $1 / \mathrm{s}$ & $10^{-5}$ \\
\hline Univerzalna plinska konstanta, $R$ & $\mathrm{~kJ} / \mathrm{molK}$ & $8,31 \times 10^{-3}$ \\
\hline Aktivacijska energija difuzije klorida, $U$ & $\mathrm{~kJ} / \mathrm{mol}$ & 44,6 \\
\hline Toplinska vodljivost, $\lambda$ & $\mathrm{W} / \mathrm{mK}$ & 2,1 \\
\hline Toplinski kapacitet, $c$ & $\mathrm{~J} / \mathrm{kgK}$ & 900 \\
\hline Konvektivni koeficijent, $B_{T}$ & $\mathrm{~W} / \mathrm{m}^{2} \mathrm{~K}$ & 9 \\
\hline Gustoća betona, $\rho$ & $\mathrm{kg} / \mathrm{m}^{3}$ & 2500 \\
\hline Volumni udio vode u saturiranom betonu, $w_{d}$ & $\mathrm{~m}^{3} / \mathrm{m}^{3}$ & 0,1 \\
\hline Faktor oblika, $n$ & - & 6,4 \\
\hline $\begin{array}{l}\text { Koeficijent difuzije kapilarne vode u } \\
\text { neraspucalom betonu, } D_{0}\end{array}$ & $\mathrm{~m}^{2} / \mathrm{s}$ & $2,2 \times 10^{-10}$ \\
\hline $\begin{array}{l}\text { Koeficijent difuzije kloridnih iona u } \\
\text { neraspucalom betonu, } D_{c, R e f}\end{array}$ & $\mathrm{~m}^{2} / \mathrm{s}$ & $5,5 \times 10^{-12}$ \\
\hline
\end{tabular}

Pukotina je modelirana na način da je koeficijent difuzije kapilarne vode $D_{0}$ ovisan o širini same pukotine. Oblik krivulje za difuznost u pukotini (Slika 2), primijenjen u modelu, dobiven je na temelju eksperimentalnih rezultata za permeabilnost u raspucanom i potpuno saturiranom betonu [2]. Utjecaj pukotina na povećanje koeficijenta difuzije vode usvojen je na način da se koeficijent difuzije faktorizira normaliziranim koeficijentom permeabilnosti. Stoga za širinu pukotine $0,075 \mathrm{~mm}$ vrijednost koeficijenta difuzije kapilarne vode iznosi $3,9 \times 10^{-10}$, dok je za širinu pukotine $0.1 \mathrm{~mm}$ korištena vrijednost $2,9 \times 10^{-9}$. Treba naglasiti da se na licu stupa pretpostavlja maksimalna širina pukotine, koja se zatim smanjuje prema vrhu pukotine. Kako nije točno određeno na koji način se širina pukotine smanjuje, u modelu se pretpostavlja linearno smanjenje koeficijenta difuzije od lica stupa do vrha pukotine. Naravno, na vrhu pukotine koeficijent difuzije kapilarne vode poprima vrijednost za neraspucalo stanje betona. 

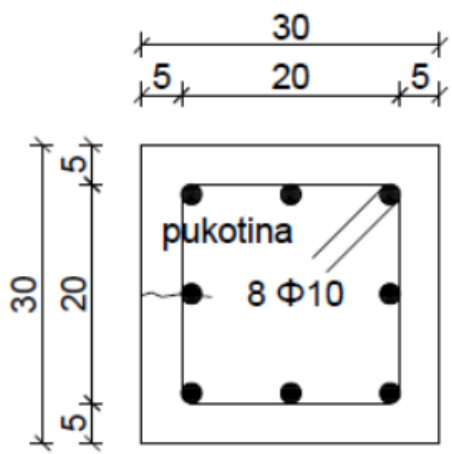

Slika 1. Poprečni presjek kvadratnog armiranobetonskog stupa

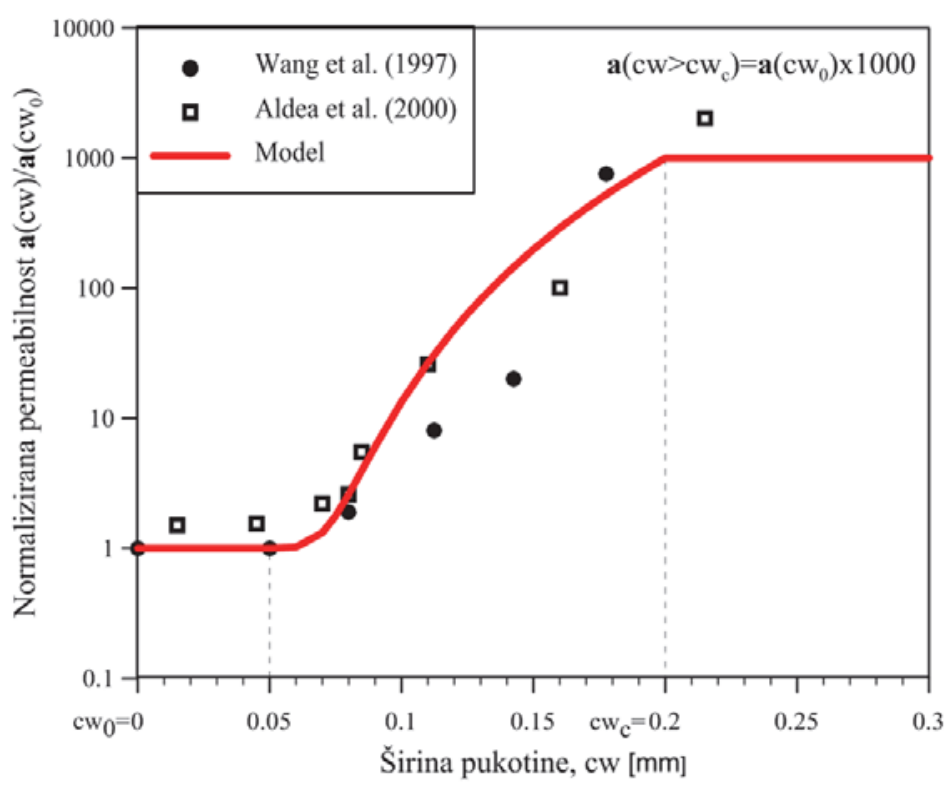

Slika 2. Normalizirana permeabilnost u ovisnosti o širini pukotine [2]

Početni i rubni uvjeti prikazani su u Tablici 2. Vidljivo je da u početnom trenutku u poprečnom presjeku nisu prisutni kloridni ioni, a i volumni udio kapilarne vode je vrlo mali. Zatim se poprečni presjek izlaže konstantnoj koncentraciji kloridnih iona koja odgovara vrlo agresivnom okolišu [2],[7], te znatno većem volumnom udjelu kapilarne vode. Nadalje, temperatura okoline zadana je kao sinusna krivulja koja ima maksimalnu vrijednost $30^{\circ} \mathrm{C}$ i minimalnu vrijednost od $-10^{\circ} \mathrm{C}$, a period sinusne krivulje je jedna godina. Takav način zadavanja rubnih uvjeta oponaša promjenu 
temperature s obzirom na godišnja doba. Treba napomenuti da proračun započinje u jesenskom razdoblju s prosječnom temperaturom od $10^{\circ} \mathrm{C}$. $\mathrm{Na}$ Slici 3 dodatno je prikazano na koji način temperatura utječe na koeficijent difuzije klorida. Vidljivo je da se za minimalnu temperaturu (zimsko razdoblje) koeficijent difuzije značajno smanji u odnosu na referentnu vrijednost, dok se u ljetnom razdoblju poveća za otprilike $50 \%$ u odnosu na referentni koeficijent difuzije.

Tablica 2. Početni i rubni uvjeti

\begin{tabular}{|l|c|c|}
\hline \multicolumn{1}{|c|}{ Parametar } & Početni uvjet & Rubni uvjet \\
\hline Volumni udio kapilarne vode, $\theta_{w}$ & $0,01 \mathrm{~m}^{3} / \mathrm{m}^{3}$ & $0,09 \mathrm{~m}^{3} / \mathrm{m}^{3}$ \\
\hline Temperatura, $T$ & $10^{\circ} \mathrm{C}$ & sinusoida \\
\hline Koncentracija slobodnih kloridnih iona, $C_{c}$ & $0 \mathrm{~kg} / \mathrm{m}^{3}$ & $20 \mathrm{~kg} / \mathrm{m}^{3}$ \\
\hline Koncentracija vezanih kloridnih iona, $C_{c b}$ & $0 \mathrm{~kg} / \mathrm{m}^{3}$ & - \\
\hline
\end{tabular}

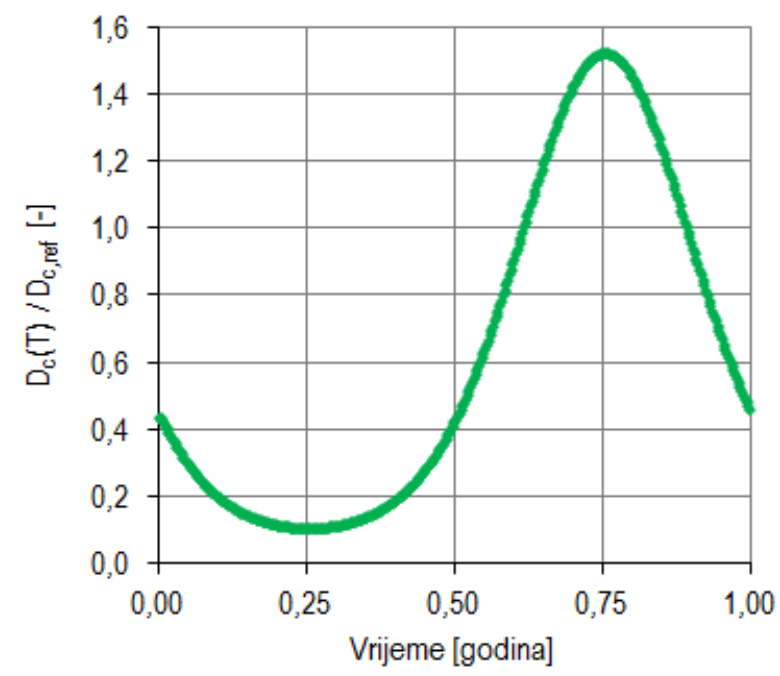

Slika 3. Utjecaj temperature na koeficijent difuzije kloridnih iona

\subsection{Rezultati numeričke analize i diskusija}

U numeričkoj analizi usvojeni su sljedeći proračunski parametri:

- Vremenski korak: $\Delta t=0.25$ dana

- Ekvidistantni prostorni koraci: $\Delta x=\Delta y=0.01 \mathrm{~m}$

- Kritična koncentracija kloridnih iona: $C_{c, c r i t}=7 \mathrm{~kg} / \mathrm{m}^{3}$ [2] 
Poprečni presjek bez oštećenja prvi je proračunat (Slika 4) kako bi se rezultati kasnije mogli usporediti s rezultatima za raspucale presjeke. Vidljivo je da niti nakon 50 godina, što je projektirani uporabni vijek za uobičajene građevine i mostove manjeg značaja, koncentracija kloridnih iona u blizini armature nije dosegla kritičnu vrijednost. Dakle, ukoliko presjek nije oštećen i zaštitni sloj betona je dovoljno velik, depasivacija armature ne bi se trebala pojaviti dugi niz godina. No, vrlo je teško zamisliti betonsku konstrukciju bez pukotina jer one nastaju zbog niza razloga kao što su opterećenje, puzanje i skupljanje betona, temperaturne promjene itd. Na Slici 5 dodatno su prikazane koncentracije slobodnih klorida na četvrtini presjeka zbog dvostruke simetrije za različita vremena izloženosti presjeka.

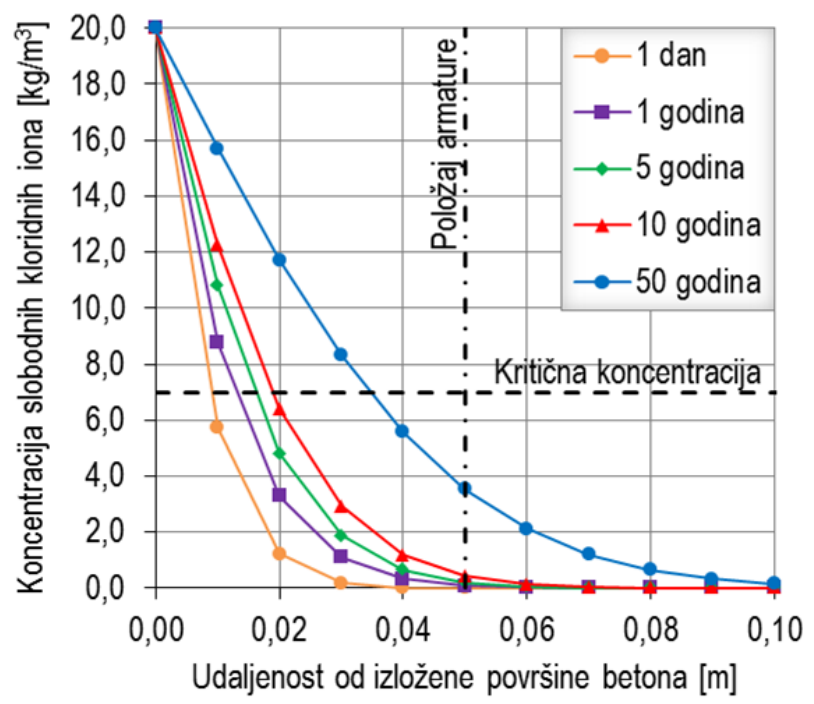

Slika 4. Koncentracija slobodnih kloridnih iona u ovisnosti o udaljenosti od izložene površine betona za presjek po sredini stupa 
a)

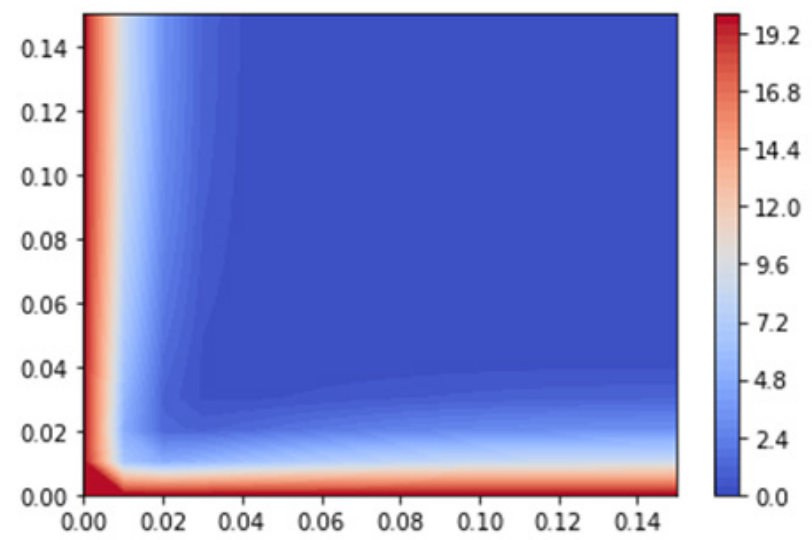

b)

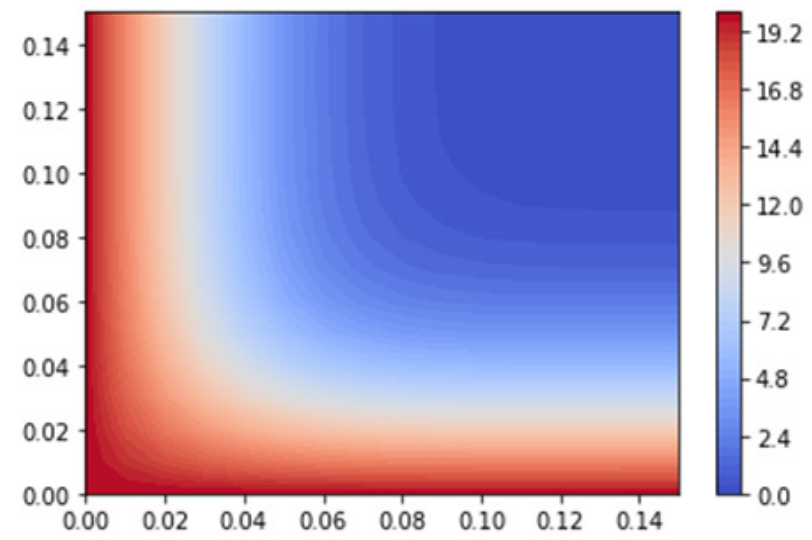

Slika 5. Koncentracije slobodnih kloridnih iona nakon:

a) 1 godine, b) 50 godina

Nadalje, isti proračun ponovljen s modeliranom pukotinom širine 0,075 $\mathrm{mm}$ te $0,1 \mathrm{~mm}$. Rezultati su prikazani na Slici 6 te pokazuju da kloridni ioni znatno lakše penetriraju u betonski presjek s porastom širine pukotine. Za širinu pukotine $0,075 \mathrm{~mm}$ zabilježen porast koncentracija u odnosu na referentni slučaj, ali on nije toliko drastičan jer je modificirani koeficijent difuzije kapilarne vode tek dvostruko veći referentnog. Nasuprot tome, za pukotinu širine $0,1 \mathrm{~mm}$ taj koeficijent je značajno veći što dovodi i do znatno brže penetracije kloridnih iona u beton, što rezultira dostizanjem kritične koncentracije za samo tri dana izloženosti poprečnog presjeka. 


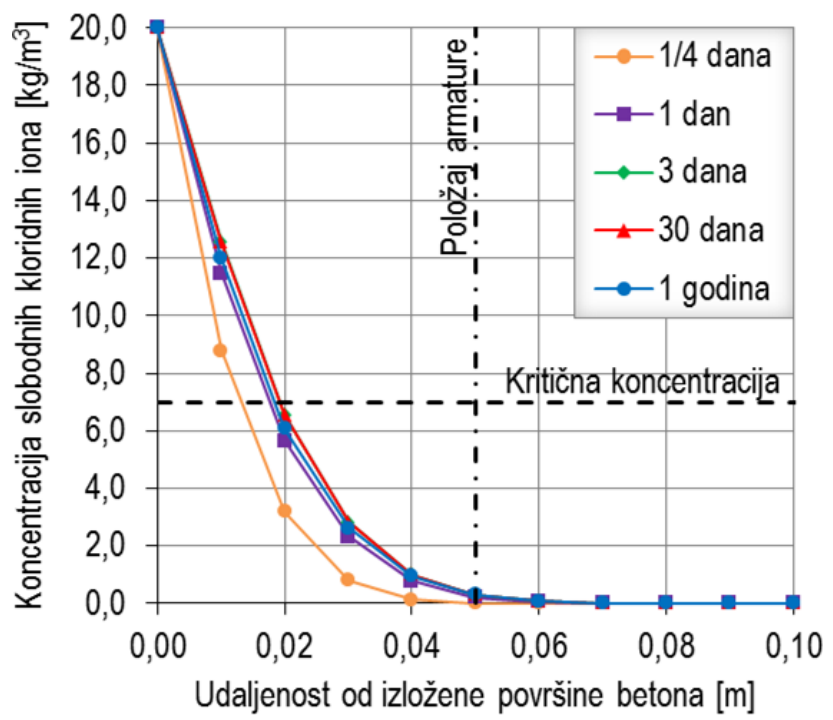

a)

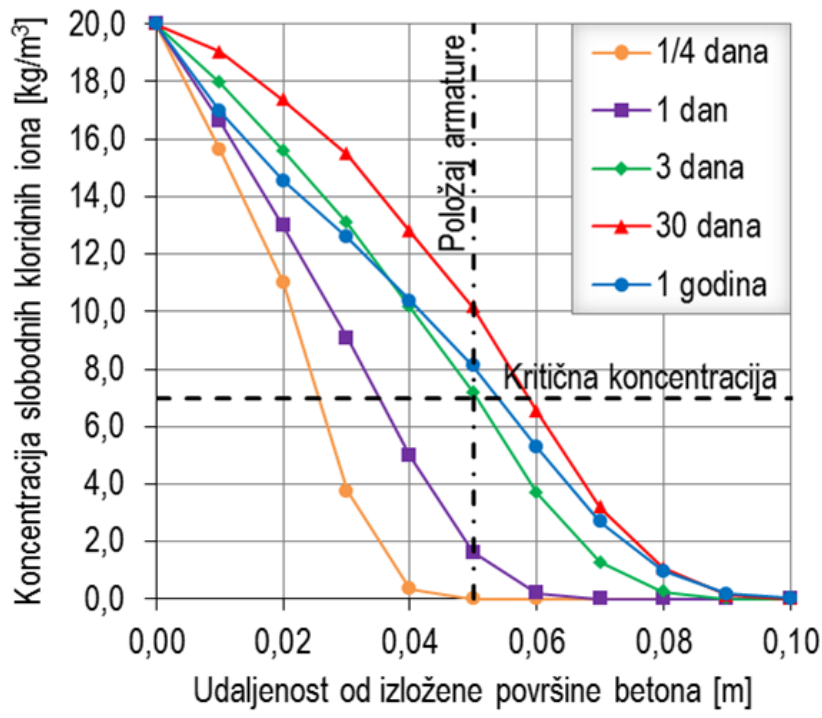

Slika 6. Koncentracija slobodnih kloridnih iona u ovisnosti o udaljenosti od izložene površine betona za presjek po sredini stupa (kroz pukotinu) za:

a) pukotinu širine $0,075 \mathrm{~mm}, b)$ pukotinu širine $0,1 \mathrm{~mm}$

Isto tako, treba primijetiti da se koncentracija kloridnih iona duž pukotine s vremenom smanjuje, što je posebno vidljivo na Slici 6b. Ova pojava može se objasniti činjenicom da se uravnotežavanjem sadržaja kapilarne vode u presjeku smanjuje njen gradijent. Posljedično, konvektivni prijenos klorida prestaje biti dominantan i transport se nadalje odvija 
prvenstveno difuzivnim putem. Dakle, kloridni ioni šire se u beton oko pukotine (Slika 7). Spomenuta pojava prikazana je i na Slici 8, gdje se vidi prestanak rasta koncentracije iona nakon 10 dana izloženosti za točku na armaturi. Naravno, nakon određenog vremena koncentracija duž pukotine će ponovno početi rasti jer će se i koncentracije u blizini pukotine povećati.

a)

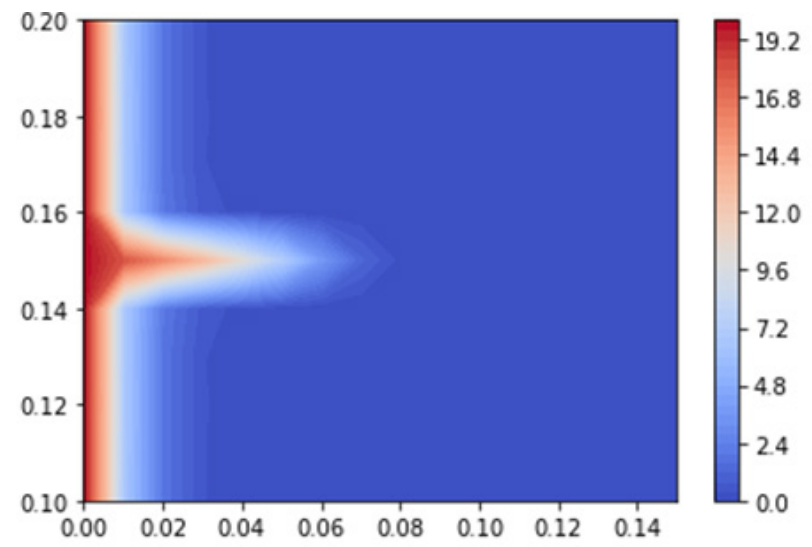

b)

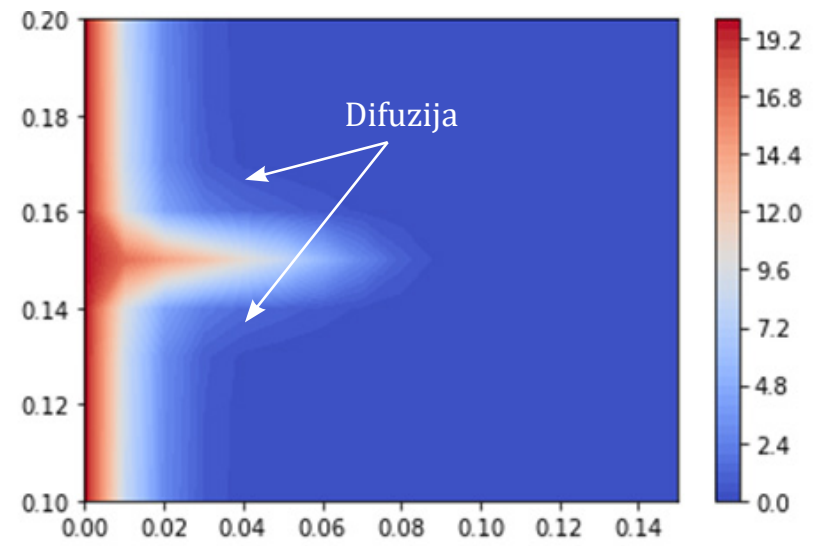

Slika 7. Koncentracije slobodnih kloridnih iona za širinu pukotine 0,1 mm nakon:

a) 3 dana, b) 1 godine

U slučaju pukotine širine $0,1 \mathrm{~mm}$ kritična koncentracija kloridnih iona zabilježena je već nakon 3 dana izloženosti, što je vrlo ekstremno. No, treba naglasiti da je u ovom slučaju presjek s vrlo malim volumnim udjelom kapilarne vode izložen velikom povećanju sadržaja kapilarne vode i izuzetno agresivnom okolišu $\left(20 \mathrm{~kg} / \mathrm{m}^{3}\right)$. Za usporedbu, mogu se pogledati izmjerene vrijednosti koncentracije slobodnih klorida na Krčkom mostu [8], pri čemu maksimalna koncentracija iznosi $10,75 \mathrm{~kg} / \mathrm{m}^{3}$. Usvojeni 
rubni uvjeti rezultiraju velikim gradijentom kapilarne vode u kojoj se nalazi velika koncentracija kloridnih iona. Dakle, rubni uvjeti predstavljaju ekstremnu situaciju, čija je vjerojatnost pojave u praksi vrlo mala. No, važno je primijetiti da pojava širih pukotina značajno ubrzava prodor kloridnih iona te posljedično smanjuje trajanje faze inicijacije.

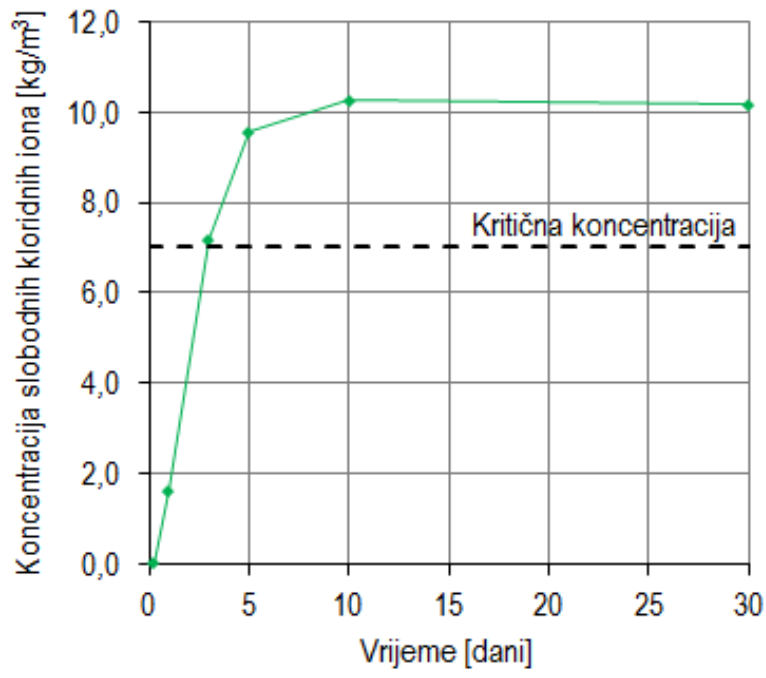

Slika 8. Koncentracije slobodnih kloridnih iona u vremenu za točku na armaturi (pukotina širine $0,1 \mathrm{~mm}$ )

\section{Zaključak}

Oštećenja armiranobetonskih konstrukcija uslijed pojave korozije mogu imati značajne posljedice na nosivost i trajnost. Za svaku armiranobetonsku konstrukciju najpovoljnije je da faza inicijacije potraje što dulje ili da do korozije armature niti ne dođe. U okviru ovog rada razvijen je 2D numerički model temeljen na metodi konačnih razlika koji omogućuje određivanje trenutka u kojem dolazi do depasivacije armature. Kako bi to bilo moguće, simulirani su transportni procesi kapilarne vode, kloridnih iona te prijenos topline. Primjena modela pokazana je na primjeru kvadratnog armiranobetonskog poprečnog presjeka gdje se ispitivao utjecaj pukotine na trajanje faze inicijacije. Rezultati pokazuju da se s povećanjem širine pukotina u zaštitnom sloju betona značajno skraćuje trajanje faze inicijacije te se depasivacija armature javlja vrlo brzo nakon izlaganja poprečnog presjeka agresivnom okolišu. Ova pojava rezultat je konvektivnog dijela jednadžbe za transport kloridnih iona. Utjecaj konvektivnog dijela naglo 
opada sa smanjenjem gradijenta kapilarne vode pa se transport kloridnih iona nakon toga odvija kao difuzivni proces koji je znatno sporiji.

Razvijeni model daje dobar uvid u ponašanje transportnih procesa koji se događaju u armiranobetonskom poprečnom presjeku. No, u budućnosti model je svakako potrebno validirati eksperimentalnim istraživanjima. Osim toga, rubne uvjete moguće je stohastički modelirati kako bi se vjerodostojnije oponašalo stvarno stanje.

\section{Literatura}

[1] Martín-Pérez, B. (1999) Service Life Modelling of RC Highway Structures Exposed to Chlorides. PhD thesis, University of Toronto, Canada

[2] Kušter Marić, M. (2013) Predviđanje uporabnog vijeka armiranobetonskih mostova izloženih kloridima. Doktorski rad. Sveučilište u Zagrebu, Hrvatska

[3] Bažant, Z. P. (1979a) Physical Model for Steel Corrosion in Concrete Sea Structures - Theory. Journal of the Structural Division, ASCE, 105 (ST6), pp. 1137-1153.

[4] Bažant, Z.P. (1979b) Physical Model for Steel Corrosion in Concrete Sea Structures - Application. Journal of the Structural Division, ASCE, 105, pp. 1155-1166.

[5] Saetta, A., Scotta, R., Vitaliani, R. (1993) Analysis of Chloride Diffusion into Partial1y Saturated Concrete. ACI Materials Journal, 90 (5), pp. 441-451.

[6] Bear, J. \& Bachmat, Y. (1991) Introduction to Modelling of Transport Phenomena in Porous Media. Kluwer Academic Publishers: Dordrecth.

[7] Ožbolt, J., Balabanić, G., Periškić, G., Kušter, M. (2010) Modelling the Effect of Damage on Transport Processes in Concrete. Construction and Building Materials, 24(9), pp. 1638-1648.

[8] Torić, N., Balabanić, G., Kožar, I. (2010) Proračun prodora klorida u armiranobetonski stup. GRAĐEVINAR, 62 (2), pp. 133-139.

[9] Solving nonlinear ODE and PDE problems. https://hplgit.github.io/nummethods-for-PDEs/doc/pub/nonlin/pdf/nonlin-4print.pdf (15.07.2019.)

[10] Farlow, S. J. (1982) Partial Differential Equations for Scientists and Engineers. John Wiley \& Sons: New York 